\title{
O Sistema do Mérito e o Ensino
}

$\mathrm{N}$

ENHUM instrumento de aferição da eficiência quantitativa e qualitativa do ensino é mais valioso do que o concurso para preenchimento dos cargos públicos. Isso se deve ao fato de que a grande variedade das funções compreendidas na órbita dos șerviços do Estado moderno põe em jogo conhecimentos de tôda natureza, desde as noções gerais mais elementares até os mais especializados e complexos conceitos que a inteligência humana é capaz de conceber. $E$ como tais conhecimentos são ministrados através do aparelhamento educacional comum, os concursos para os cargos públicos adquirem o cunho de um teste completo do rendimento do ensino, em todos os ramos e graus que êste último comporta.

A riqueza de sugestões e de advertências que um teste dessa espécie pode proporcionar ao planejamento dos sistemas educacionais é tão ampla, que chega a surpreender o pouco interêsse que por ela manifestam os nossos educadores.

No seu aspecto subjacente de pesquisa pedagógica, e por fôrça mesmo da sua instituição como atividade constante, os concursos para ingresso no funcionalismo público oferecem a vantagem de apresentar indicações que se renovam com muita freqüência, e que, portanto, asseguram bases sempre atualizadas ao trabalho do estudioso das questões da pedagogia prática.

Eis aí mais uma razão a recomendá-los ao interêsse dos círculos orientadores do ensino, onde será fácil reconhecer que não há muitos outros processos igualmente capazes de proporcionar uma verificação simultânea e fidedigna dos problemas do rendimento didático, da adaptação dos currículos às realidades da vida prática, das variações locais da eficiência dos métodos de aprendizagem.

Não se pode esperar que o ensino se desenvolva de maneira equilibrada e em consonância com as condições gerais da evolução do país, se os recursos de que êle dispuser forem distribuídos empiricamente, por falta de um adequado conhecimento do volume da 
formação de pessoal, nos diversos setores das atividades profissionais.

Sob êsse aspecto, sobretudo quando, como sucede entre nós, - Estado, na sua função de empregador, domina e orienta quase sòzinho os mercados de trabalho, muito se pode lucrar da análise das inscrições aos concursos para o serviço público, de vez que elas, refletindo as proporções entre a oferta e a procura da mão de obra nas diferentes profissões, permitem identificar onde há excesso ou carência de formação de pessoal.

Por outro lado, quando se põem em confronto as noções de seleção e de ensino é difícil omitir a motivação com que os concursos para ingresso nos quadros do funcionalismo beneficiam a missão dos educadores, através do estímulo e da influência salutar que exercem sôbre a juventude das escolas e as pessoas que the devem assistência no âmbito familiar. Daí não decorre, apenas, um meIhor ajustamento de dois fatôres indispensáveis ao êxito de qualquer sistema educacional, o interêsse do aluno pela aprendizagem e a cooperação do lar à escola - senão também uma concepção mais exata das finalidades do ensino. Como forma de competição em que a vitória cabe aos mais capazes, o concurso contribui para reŚnerar o ensino e libertá-lo daquela tendência que a alcunha "diplomania" traduz com admirável nitidez.

Já se lançou, com pretensóes de aforisma, a afirmação de que - Estado como empregador sofre a influência do Estado como educador. A recíproca não é menos verdadeira, e isso se tornará de tôda a evidência no dia. em que os educadores se detiverem na análise dos resultados dos concursos para os cargos públicos, com o propósito de pesquisar o que êles encerram como advertência e orientação.

Num país como o nosso, de grandes contrastes, mas sem grandes conflitos, onde, por isso mesmo, os problemas educacionais tendem a disfarçar sua verdadeira fisionomia, o trabalho de pesquisa se reveste de especial importância. Não se devem, pois, desprezar as oportunidades de realizá-lo e de através dêle buscar melhores soluções para a crise do ensino.

Eis porque chamamos a atenção dos nossos educadores para o valioso subsidio que thes oferece o sistema do mérito como instrumento de pesquisa, fator de melhoria das práticas educacionais e estimulante do interêsse dos pais e alunos pelas verdadeiras finalia'ades do ensino. 